Proc. Estonian Acad. Sci. Biol. Ecol., 2006, 55, 2, 123-136

\title{
Needle carbohydrate concentrations in Norway spruce as affected by wood ash application to soil
}

\author{
Jaan Klõšeiko*, Malle Mandre, and Reet Korsjukov \\ Department of Ecophysiology, Institute of Forestry and Rural Engineering, Estonian University of \\ Life Sciences, Viljandi mnt. 18B, 11216 Tallinn, Estonia \\ Received 9 December 2005, in revised form 3 March 2006

\begin{abstract}
Sandy soil in a tree nursery was treated with wood ash $\left(0.25,0.5\right.$, or $1.0 \mathrm{~kg} \mathrm{~m}^{-2}$, untreated for control). The influence of different treatments on the carbohydrate concentration and dynamics in needles was estimated. The increase in the $\mathrm{pH}$ of soil due to wood ash application correlated with the reduction in the needle hexoses (glucose and fructose). The ratio of fructose to glucose in treated trees often exceeded 2-3 times the respective hexose ratio in untreated trees. The sucrose concentration was not significantly influenced by the soil $\mathrm{pH}$ and wood ash. The starch concentration tended to be smaller in treated trees. The results suggest that carbohydrate reserves in needles could be reduced by wood ash during the growing period. The accumulation of soluble carbohydrates by winter did not depend on the treatment.
\end{abstract}

Key words: alkaline soil, biochemical markers, fructose, glucose, starch, sucrose.

\section{INTRODUCTION}

In recent years environmental protection concerns have caused increased interest in the utilization of various industrial residues and their possible use de novo in different branches of economy. The use of wood ash as an additional fertilizer is of great interest from the perspective of maintaining the nutrient balance in managed forest ecosystems in areas from where timber has been removed. However, research into the effects of alkaline wood ash on the physiology

${ }^{*}$ Corresponding author, jkl@rmk.ee 
of trees is insufficient and no information is available on the effect of wood ash on the metabolism of carbohydrates - the main initial compounds for metabolism, growth, and bioproduction of plants.

The physiological mechanisms by which plants change the carbon allocation between various sinks, the resulting changes in the carbohydrate levels in needles and consequences to the growth and development of trees are not finally clear. There may be several external or internal factors that influence the carbon allocation and carbohydrate metabolism in the plant organism, in which the chemical character of the growth substrate and mineral nutrition processes play a great role. Direct effects of the soil reaction $(\mathrm{pH})$ on the uptake of nutrients by root are shown by many authors (Lindberg \& Yahya, 1994; von Wirén et al., 1997; Schachtman et al., 1998). Restricted availability of essential nutrients in alkaline soil should be counteracted by the distribution of assimilates from shoots to roots in order to maintain the functional equilibrium between the uptake of nutrients and the carbohydrate supply.

Carbohydrates are potentially useful in qualifying the physiological state of trees, which need not be immediately expressed in the change of growth. After acclimation of trees in autumn the soluble carbohydrate levels are known to indicate the frost hardiness of trees (Aronsson et al., 1976; Ögren, 1999). Sucrose, hexoses, and starch respond differently to the substantial alterations in the nutrient balance (Wingler et al., 1994). Carbohydrates, which are most responsive to alterations in growth conditions, could be useful as potential indicators of the stress tolerance of trees (Ayres \& West, 1993; Lawlor \& Keys, 1993; Pate, 1993). Carbohydrate analysis would facilitate an early assessment of the health status of trees to avoid the costly remedy of unexpected consequences.

Wood ash is alkaline and contains predominantly $\mathrm{K}^{+}, \mathrm{Ca}^{2+}$, and $\mathrm{Mg}^{2+}$ (Eriksson, 1998; Larsson \& Westling, 1998; Mandre et al., 2004) and causes several nutritional changes in soil and in plant. In cotton the glucose concentration is reduced while sucrose and fructose concentrations are affected inconsistently by $\mathrm{K}$ fertilization in field (Pettigrew, 1999). It is known that $\mathrm{K}$ and $\mathrm{Mg}$ limitation may reduce photosynthesis or translocation of carbohydrates from shoot in nutrient poor soils (Ericsson et al., 1996; Marschner et al., 1996). Thus enrichment of soils with nutrients from wood ash should positively influence the carbon balance in plants and moderate alkalization of wood ash treated soil should not diminish the acquisition of nutrients with reduced mobility.

This study was undertaken to estimate the effect of wood ash fertilization on the concentration of carbohydrates in Norway spruce needles. Most studies on the carbohydrate and environment interactions usually concentrate on soluble carbohydrates. In the current study the fraction of soluble carbohydrates was analysed in some detail to find out the most responsive carbohydrate fractions to the alkalization of growth substrate and to estimate the physiological state of trees under the influence of wood ash. 


\section{MATERIAL AND METHODS}

Plant material and soil treatment

Norway spruce (Picea abies (L.) Karst.) 4-year-old seedlings were planted in the Raudalu nursery $\left(59^{\circ} 22^{\prime} 11^{\prime \prime} \mathrm{N}, 2^{\circ} 45^{\prime} 29^{\prime \prime} \mathrm{E}\right)$ in Estonia in spring 2000. The seedlings used in the experiment were grown up from the seeds of the same mother tree and cultivated in the same nursery before planting. At the beginning of July 2000, the soil under the trees was treated with raw fly ash. Treatments with wood ash (WA) were carried out with different doses:

1. control, untreated sample area $\left(100 \mathrm{~m}^{2}\right)$,

2. $0.25 \mathrm{~kg} \mathrm{~m}^{-2}\left(50 \mathrm{~m}^{2}\right)$,

3. $0.5 \mathrm{~kg} \mathrm{~m}^{-2}\left(50 \mathrm{~m}^{2}\right)$,

4. $1 \mathrm{~kg} \mathrm{~m}^{-2}\left(100 \mathrm{~m}^{2}\right)$.

The density of the planted seedlings in the sample plots was 1 seedling per square metre.

The soil in the nursery was nutrient-poor sandy soil. However, as a result of digging, in the nursery the soil has lost its natural characteristics and it can be described as a nutrient-poor growth substrate affected by human activity.

In the experiment WA from Türi (Estonia) heating plant was applied. This plant uses for combustion both deciduous and coniferous wood. The chemical composition of the WA was the following: $0.025 \% \mathrm{~N}, 1.6 \% \mathrm{P}, 1.0 \% \mathrm{~S}, 0.33 \% \mathrm{Al}$, $0.16 \% \mathrm{~B}, 12.3 \% \mathrm{Ca}, 0.020 \% \mathrm{Cu}, 1.0 \% \mathrm{Fe}, 4.8 \% \mathrm{~K}, 1.9 \% \mathrm{Mg}, 1.8 \% \mathrm{Na}, 0.99 \% \mathrm{Mn}$, $0.008 \% \mathrm{~Pb}$, and $0.43 \% \mathrm{Zn}$ (Mandre et al., 2004).

\section{Needle samples}

Samples were collected 7 times during the period from the beginning of June 2001 until the end of January 2002. Taking into account that the response of needles from different layers of canopies to changes in the environment (light and nutrient availability) has been described to be different (Sun \& Payn, 1999; Mandre \& Tullus, 2002), shoots were collected from the selected 6-10 trees from the middle height of the crown. In addition, the dependence of carbohydrates concentration on the location of needles in the canopy under the influence of wood ash was studied. These samples were collected from different layers of the crown (bottom, middle, and top) on a separate occasion at the beginning of August.

The metabolic activity of needles collected was immediately stopped with liquid nitrogen (in a thermostat from Nalgene). After that the carbohydrates in needles were fixed by boiling in $96 \%$ ethanol for $3 \mathrm{~min}$. The fixed needles were oven-dried at $70^{\circ} \mathrm{C}$ for $8 \mathrm{~h}$. The dried needles were ground with a vibrating ball mill (Retsch, Germany). The carbohydrate concentration ( $\mathrm{mg} \mathrm{g}^{-1} \mathrm{~d}$.m.) in the samples (40-60 mg) was determined enzymatically (Steen \& Larsson, 1986) with a modification in the extraction conditions (Klõšeiko \& Mandre, 2001). 
Carbohydrates from the needle powder were extracted obtaining the initial extract of the water-soluble carbohydrates. Part of the initial extract was further subjected to the hydrolysis of sucrose and maltodextrins, which were determined from the amounts of released hexoses (glucose, and using fructose for correction). Excess bound fructose was determined as the difference of fructose and glucose released during the hydrolysis of sucrose. The glucose and fructose concentrations of different extracts were measured with the hexokinase and glucose-6-phosphate dehydrogenase indicator reaction using auxiliary isomerization of hexose phosphates with phosphoglucose isomerase. The reduction of NADP at a wavelength of $340 \mathrm{~nm}$ was measured with the spectrophotometer Helios $\alpha$ (Unicam Ltd., UK). The enzymes were obtained from Sigma-Aldrich Inc. (USA) and Merck \& Co Inc. (Germany). The method applied does not distinguish glucose and fructose from their hexose-6-phosphates. However, the concentration of glucose-6-phosphate and fructose-6-phosphate is usually by several orders of magnitude lower than that of free hexoses (Egger et al., 1996).

Starch analysis was based on the principle of AACC Method 76.13 (Total Starch..., 1998). Soluble sugars were removed with 40\% ethanol. Insoluble residue was pre-treated with dimethyl sulphoxide at $100^{\circ} \mathrm{C}$. Starch was hydrolysed in the first step with thermostable $\alpha$-amylase and in the second step with amyloglucosidase. The liberated glucose was analysed with the same method as used for the analysis of soluble carbohydrates. Carbohydrate analysis was tested with pure glucose, fructose, sucrose, starch, and raffinose (compounds obtained from Sigma-Aldrich Inc., USA; and Reachim, Russia).

Needle $\mathrm{N}$ and $\mathrm{K}$ were determined from samples each of which consisted of all current-year needles from a tree in August 2002. Three samples were analysed for mineral nutrients by the Estonian Agricultural Research Centre, which has competence according to EVS-EN ISO/IEC 17025:2001. The concentration of K was determined using an atom-adsorption analyser AAA-1N (Karl Zeiss, Germany). Nitrogen was measured by the method of Kjeldahl.

\section{Soil samples}

Soil samples were collected from five locations (depth 10-30 cm) on each plot on five dates. The individual samples were pooled in each treatment and the $\mathrm{pH}\left(\mathrm{H}_{2} \mathrm{O}\right)$ of soil was analysed with a $\mathrm{pH}$ meter (InLab412 electrode, MettlerToledo, UK) from the mixture of dried soil and distilled water $(1: 2.5 \mathrm{v}: \mathrm{v})$. Twopoint calibration with standard buffer solutions at $\mathrm{pH} 4.0$ and 7.0 was used during the measurements.

\section{Statistical tests}

Different carbohydrate forms were analysed separately with analysis of variance (ANOVA) on repeated-measures, in which the repeated factor was time and the 
category was treatment (including control). For the repeated-measures test of differences between the needles from differently treated trees only dates with duplicates were used. The duplicates were obtained by dividing the sample areas into halves. The significance of the regression was assessed with the generalized linear models (GLM) procedure, in which the independent variable was the soil $\mathrm{pH}$ and the category was the date. The assumption of statistically dependent samples in GLM was abandoned. This was justified by the significant $(P<0.05)$ results of repeated-measures ANOVA. Variability in means between the layers was estimated with ANOVA using treatment and layer as categorical effects. In ANOVA the interaction was always included into the model. Statistics were calculated with Systat 10.0 for Windows (Systat Software GmbH, Germany).

\section{RESULTS}

\section{Soil}

Earlier the increases of $\mathrm{K}, \mathrm{Ca}, \mathrm{Mg}$, and $\mathrm{B}$ were described as a result of WA treatment (Mandre et al., 2004). On WA treated areas an elevated $\mathrm{pH}$ of soil was found and the differences were dependent on season (Fig. 1). In June and July the $\mathrm{pH}$ values of areas were ordered according to the dose of WA. The area with the largest applied dose had the highest $\mathrm{pH}(7.8-8.0)$ and the difference between the control and the smallest, $0.25 \mathrm{~kg} \mathrm{~m}^{-2}$ treatment, was small. However, in autumn the sequential ordering between the treatment areas disappeared while the $\mathrm{pH}$ of the untreated soil was much lower than the $\mathrm{pH}$ of the treated soils.

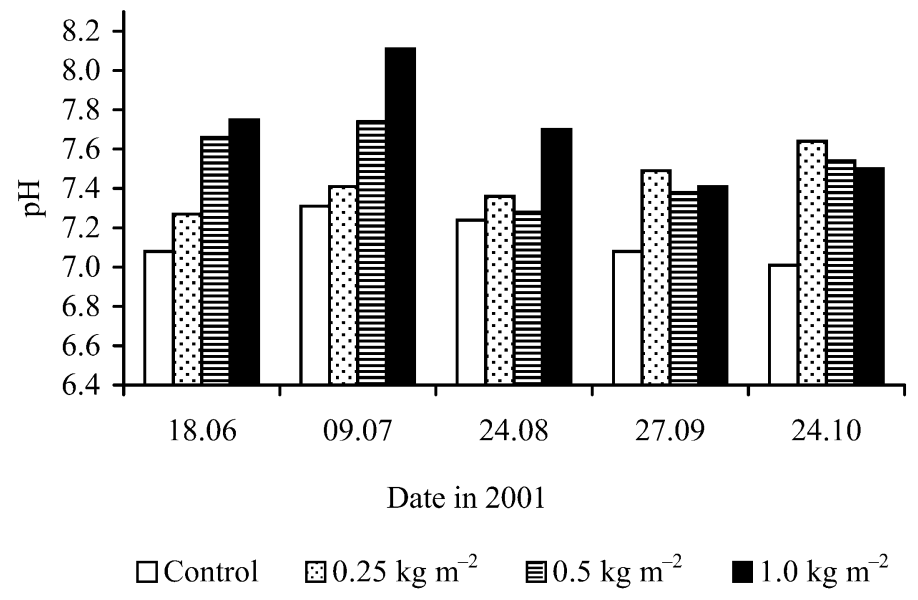

Fig. 1. The $\mathrm{pH}\left(\mathrm{H}_{2} \mathrm{O}\right)$ of the soil treated with different amounts of wood ash. Control, untreated. 


\section{Carbohydrates}

Studies of the seasonal dynamics of hexoses in Norway spruce needles showed that hexoses (glucose and fructose) were responsive to changes in the growth conditions and indicative of differences between the variants of treatment. The mean concentrations of glucose and fructose were lower $(P<0.05)$ in needles from treated trees than in control (Fig. 2). During the second half of summer, the concentration of hexoses decreased more steeply in the needles of treated trees than in control resulting in a substantial reduction in the concentration of hexoses by the end of summer. In July (on two dates) the concentration of hexoses was reduced according to the amounts of the applied WA and an increase in the soil alkalinity was observed. Later the differences between treatments were smaller, while the differences from control were still large. The concentration of glucose was affected by the treatments more than the concentration of fructose. This was indicated by the higher ratio of fructose to glucose in the needles of treated trees.
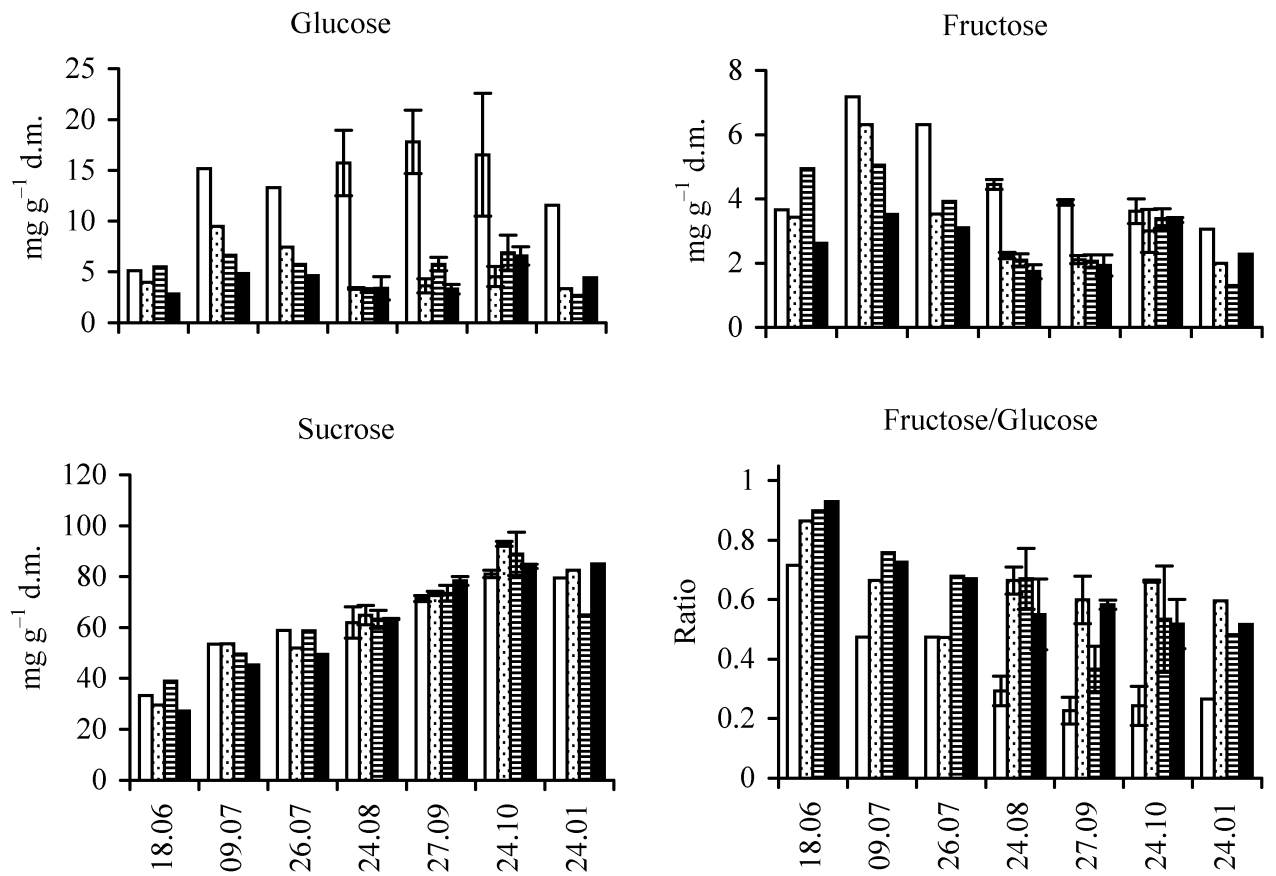

Date in 2001 and 2002

$\square$ Control

$$
0.25 \mathrm{~kg} \mathrm{~m}^{-2}
$$

$$
\text { 目 } 0.5 \mathrm{~kg} \mathrm{~m}^{-2}
$$$$
1.0 \mathrm{~kg} \mathrm{~m}^{-2}
$$

Fig. 2. Dynamics in the concentration of hexoses (glucose and fructose) and sucrose in current-year needles of young Norway spruce grown on soil treated with different amounts of wood ash. Control, untreated; joined sample from 6-10 trees; endpoints of bars indicate the values of two samples obtained by splitting the treatment area from August-October. 
The concentration of sucrose in needles was increasing step by step after budbreak and there were no essential differences between the treatments (Fig. 2). Still, in summertime, until the end of July, the smallest sucrose levels were found for the largest WA dose. ANOVA of the averages across the whole measurement period suggested no significant differences in the needle sucrose concentration between the treatments $(p=0.997)$.

On WA treated areas the starch concentration of needles tended to be lower than control ( $p=0.099)$ (Fig. 3). Larger differences were found for larger doses and in summer. At the beginning of July and at the end of August, the starch concentration
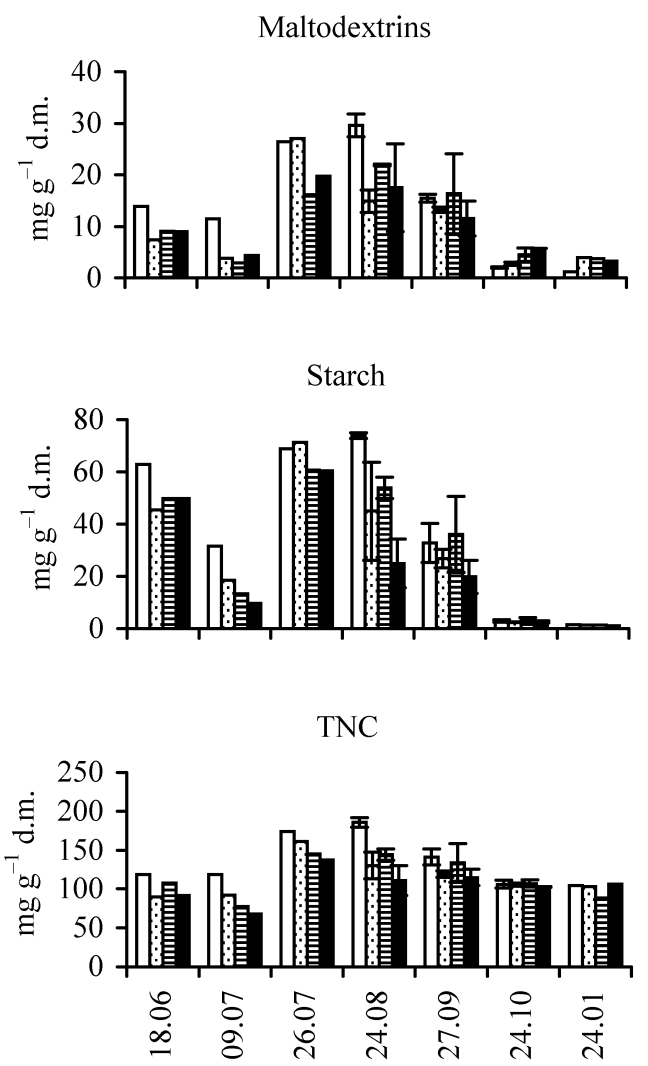

Date in 2001 and 2002
$\square$ Control
$0.25 \mathrm{~kg} \mathrm{~m}^{-2}$
目 $0.5 \mathrm{~kg} \mathrm{~m}^{-2}$
- $1.0 \mathrm{~kg} \mathrm{~m}^{-2}$

Fig. 3. Dynamics in the concentration of maltodextrins, starch, and sum of carbohydrates (TNC, including sucrose and hexoses) in current-year needles of young Norway spruce grown on soil treated with different amounts of wood ash. Control, untreated; joined sample from 6-10 trees; endpoints of bars indicate the values of two samples obtained by splitting the treatment area from August-October. 
of the needles in the treatment with the largest dose $\left(1.0 \mathrm{~kg} \mathrm{WA} \mathrm{m}^{-2}\right.$ soil $)$ was about 2-3 times lower than in the needles of untreated spruces. Maltodextrins, the soluble intermediates of starch metabolism, responded similarly to starch. Excess bound fructose (7-14 $\mathrm{mg} \mathrm{g}^{-1} \mathrm{~d}$.m.) was found only in January. The total carbohydrate concentration was little or not affected on the sample collection dates in autumn and winter.

The concentration of glucose and the ratio of hexoses were significantly correlated with the $\mathrm{pH}$ of soil (GLM, $P<0.01$ ) (Figs 1 and 2). The increased $\mathrm{pH}$ values tended to decrease the glucose concentration in needles and to increase both the ratio of fructose to glucose and sucrose to hexoses.

The concentrations of starch, maltodextrines, and total measured carbohydrates in needles had a tendency of increasing toward the top of control trees, but the sucrose levels were relatively similar in different parts of the crown (Fig. 4). Our
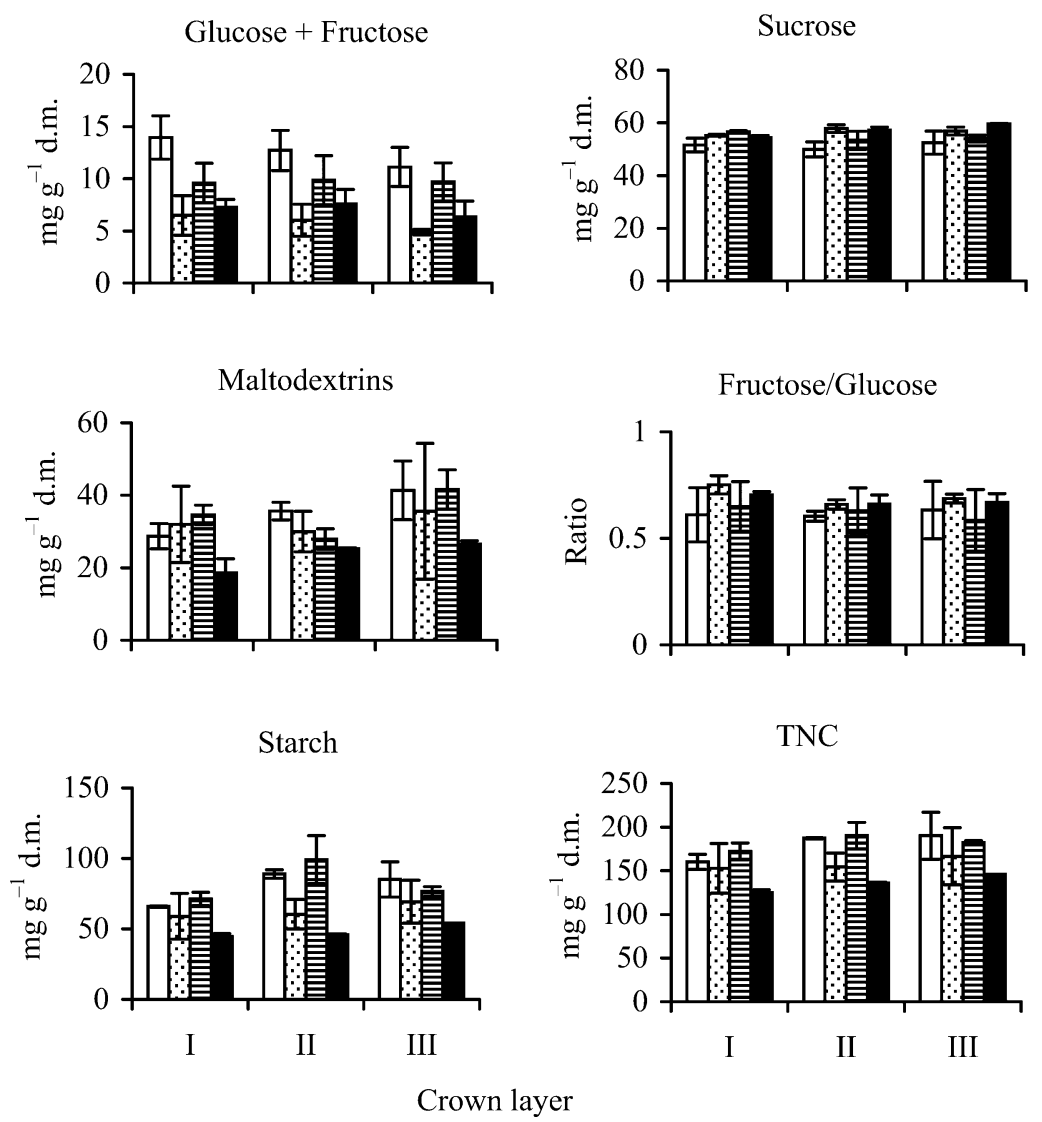

Fig. 4. Concentration of carbohydrates in current-year needles of young Norway spruce grown on soil treated with different amounts of wood ash. Samples were collected on 9 Aug 2001. Roman numbers indicate the crown layers ordered from bottom to top; control, untreated soil; mean, endpoints of bars indicate the values of two samples obtained by splitting the treatment areas. $\mathrm{TNC}=$ sum of carbohyrate concentrations. 
results did not reveal any specific tendencies in respect to treatments between the layers of the crown. Again the tendency toward a reduction of hexoses, maltodextrins, and starch by treatments was observed but no clear indication of raised fructose to glucose ratio was found that was different from the results on other dates (Figs 2, 3, and 4). ANOVA did not yield significant $p$-values either for the influence of the layer height or for its interaction with the applied WA dose.

\section{Needle $\mathbf{N}$ and $\mathrm{K}$}

Needle $\mathrm{N}$ concentrations in the seedlings did not change from the control or had a tendency to be elevated in seedlings in the area treated with $0.5 \mathrm{~kg} \mathrm{~m}^{-2}$ WA dose (Table 1). The K concentration was larger in needles of the WA treated trees.

\section{DISCUSSION}

An increase in the soil $\mathrm{pH}$ is usually accompanied with a disbalance of mineral nutrition of plants and a decrease in the availability of several essential nutrients (Fe, Mn, Zn, N, P) (Marschner, 2002; Mandre, 1995). A rational response of plants to the deficiency of mineral nutrients should increase the allocation of carbohydrates in favour of roots because well supplied roots are capable of active ion uptake, which helps to maintain the functional balance between shoots and roots (Colpaert et al., 1996; Marschner et al., 1996; Lejay et al., 2003). The dependence of the needle carbohydrate concentration on whole tree processes could be both an advantage and a disadvantage for the use of carbohydrates in the screening of tree properties.

The increasing $\mathrm{pH}$ of soil at the intermediate application rates in autumn could be caused by the formation and movement of a buffering soil solution from the upper part of the soil. Soil reaction depends interactively on ion-exchange reactions, binding of ions with mobile organics, activity of soil microorganisms, and reduction and oxidation processes. These all require further study to establish how these soil processes are affected by WA during different seasons.

Table 1. Content of mineral elements ( $\% \mathrm{dw}, \pm \mathrm{SD}, \%$ of control, $n=3)$ in current-year needles of Norway spruce growing on the sample areas treated with wood ash and in the control in August 2002

\begin{tabular}{l|c|c|c|c}
\hline \multirow{2}{*}{ Treatment } & \multicolumn{2}{|c|}{$\mathrm{N}$} & \multicolumn{2}{c}{$\mathrm{K}$} \\
\cline { 2 - 5 } & \% d.m. & \% of control & \% d.m. & \% of control \\
\hline Control & $1.28 \pm 0.11$ & 100 & $0.30 \pm 0.01$ & 100 \\
$0.25 \mathrm{~kg} \mathrm{~m}^{-2}$ & $1.23 \pm 0.09$ & 96 & $0.65 \pm 0.08$ & 217 \\
$0.5 \mathrm{~kg} \mathrm{~m}^{-2}$ & $1.45 \pm 0.09$ & 113 & $0.69 \pm 0.03$ & 230 \\
$1.0 \mathrm{~kg} \mathrm{~m}^{-2}$ & $1.29 \pm 0.09$ & 101 & $0.77 \pm 0.05$ & 257
\end{tabular}


The results on the mineral composition of the presented experiment suggest that the application of WA to a nutrient-poor sandy soil increases the concentrations of $\mathrm{K}$ and $\mathrm{Ca}$, but decreases the $\mathrm{N}$ concentration or availability in soil (Mandre et al., 2004). These results are supported by several earlier findings (Mälkönen, 1996; Moilanen \& Issakainen, 2000; Saarsalmi et al., 2001). As a result of an increased N mineralization (Martikainen, 1985; Arvidsson, 2001) and possible loss of $\mathrm{N}$ from upper soil horizons due to the high mobility of nitrate in the soil profile (Marschner, 2002), the availability of $\mathrm{N}$ to trees may decrease. However, needle $\mathrm{N}$ concentrations did not change from the control or had a tendency to be elevated. Jacobson (2001) stated similarly that ash influences the supply of inorganic $\mathrm{N}$ available for trees. However, in the present study the reduced starch concentration of WA treated trees was difficult to explain with the changes in N availability. Maltodextrins are part of reserves and showed seasonal dynamics and responses similar to starch. To be useful in the estimation of tree quality the size of carbohydrate reserves in needles should be interpreted in the context of carbon balance, which is affected by both the photosynthesis and sink activity.

Further, it is known that changes in the carbohydrate concentration depend on the degree of base cation deficiency. Severe Mg deficiency of containerized spruce trees causes the accumulation of starch and soluble carbohydrates (Mehne-Jakobs, 1995). In contrast, in natural conditions low available $\mathrm{Mg}$ and $\mathrm{K}$ concentrations in soil solution decrease starch and the total amount of carbohydrates because the reduction in photosynthesis has a greater influence on the carbon balance than the restriction of carbohydrate export from needles (Ericsson \& Kähr, 1995; Ericsson et al., 1996). Sufficiently available base cations increase the plasticity of trees and have an effect similar to that of the nitrogen fertilization despite the negligible amount of nitrogen in WA (Genenger, 2001).

Potassium is one of the important ingredients for tree growth in WA. In soil solution $\mathrm{K}$ is an activator of the plasmamembrane ATP-ase and increases the net uptake of $\mathrm{NO}^{3-}$ (Lindberg \& Yahya, 1994; Ivashikina \& Feyziev, 1998). As suggested above, a balanced content of $\mathrm{K}^{+}, \mathrm{Mg}^{2+}$, and $\mathrm{Ca}^{2+}$ in WA should mitigate the influence of alkanization on the nutrient uptake. Pettigrew (1999) showed that $\mathrm{K}$ fertilization results in a reduced glucose concentration in cotton while starch, sucrose, and fructose are affected inconsistently. The effects of fertilizer on $\mathrm{K}$ and carbohydrates in cotton were observed in the year of treatment. In our experimental trees treated with WA, the K concentration in current-year needles was increased, but the mineral nutrients were measured from trees later than carbohydrates. We found largest and persistent reductions not only in the glucose but also in the fructose concentration of the needles from trees on the WA treated areas. Thus enrichment of soil and tissues of trees with K may be a possible reason for the reduction of the levels of glucose and other carbohydrates in current-year needles of trees treated with WA.

In needles sucrose levels are not easily changed despite the substantially altered carbohydrate metabolism and biomass partitioning due to nutrient disbalances 
(Wingler et al., 1994). In herbaceous plants the sucrose concentration correlates with the carbon export rate from leaves as shown by Grodzinsky et al. (1998), and WA treatment may increase the sink activity for sucrose. In conifer needles the regulation of sucrose export might be different from that of most herbaceous species because of the special connection between the carbohydrate producing cells and transport veins described in Norway spruce (Blechschmidt-Schneider et al., 1997).

Our observation of a correlation of needle hexoses concentration with the soil $\mathrm{pH}$ indicates that hexoses in needles could be used for the estimation of the suitability of soil conditions. It is difficult to interpret causal relationships between carbohydrate dynamics in alkalized soil. Various standpoints about responses of carbohydrate metabolism to WA application can be assumed but these require further research. An alternative presumption would be that roots consumed carbohydrates for the adaptation of nutrient uptake to the increased $\mathrm{pH}$. Currently there are no unified criteria to interpret what is the consequence of the changed carbohydrate concentration on the tree growth and development (Sudachkova et al., 1997; Ashraf \& Harris, 2004). Nevertheless, in the present experiment responsive carbohydrates were starch and hexoses, which may be good indicators for the estimation of the physiological state of Norway spruce under the influence of WA application to soil.

\section{CONCLUSIONS}

Environmentally friendly possibilities of using wood ash to improve nutrition conditions of conifers on nutrient-poor sandy soil and for regulating the physiological state of trees were studied. As a result of the application of wood ash, the $\mathrm{pH}$ of soil increased in correspondence with the amounts of the agent applied, which either inhibited the synthesis of hexoses (glucose and fructose) or intensified their use in the synthesis of polysaccharides or other products of metabolism, respiration, or biomass formation. As a consequence, the concentration of starch and maltodextrins in needles decreased. However, there were no essential changes in the concentration of sucrose, which suggests that wood ash has no influence on sucrose transport from assimilative organs to roots or storage tissues, although the wood ash dose was almost twice the dose currently considered sufficient for the recycling of base cations.

The mechanisms through which wood ash application to soil affects the plants are not yet fully understood. To exclude confounding effects on the mean values of investigated parameters, more trials with statistically uniform and independent replication or larger number of dose gradations of experimental units are required as well. However, it is evident that the altered mineral composition and $\mathrm{pH}$ of soil may cause changes in carbohydrate metabolism and hexoses may be used as indicators for the estimation of the state of forest trees in alkalized soils. 


\section{ACKNOWLEDGEMENTS}

This study was partly carried out within the project 'Wood for energy - A contribution to the development of sustainable forest management (Wood-EnMan)' supported by the European Community. Financial support of the Estonian Science Foundation (grants Nos 4725 and 6026) and the Ministry of Education and Research (project No. 0432153s02) is acknowledged. We thank Dr K. Ots and Dr H. Pärn for the help in the collection of needles and soil samples.

\section{REFERENCES}

Aronsson, A., Ingestad, T. \& Lööf, L.-G. 1976. Carbohydrate metabolism and frost hardiness in pine and spruce seedlings grown at different photoperiods and thermoperiods. Physiol. Plant., 36, 127-132.

Arvidsson, H. 2001. Wood ash application in spruce stands - effects on ground vegetation, tree nutrient status and soil chemistry. PhD Thesis. Silvestria, 221. Swedish University of Agricultural Sciences.

Ashraf, M. \& Harris, P. J. C. 2004. Potential biochemical indicators of salinity tolerance in plants. Plant Sci., 166, 3-16.

Ayres, P. G. \& West, H. M. 1993. Stress responses in plants infected by pathogenic and mutualistic fungi. In Plant Adaptation to Environmental Stress (Fowden, L., Mansfield, T. \& Stoddart, J., eds), pp. 295-311. Chapman \& Hall, London.

Blechschmidt-Schneider, S., Eschrich, W. \& Jahnke, S. 1997. Phloem loading, translocation and unloading processes. In Trees - Contributions to Modern Tree Physiology (Rennenberg, H., Eschrich, W. \& Zeigler, H., eds), pp. 139-163. Backhuys Publishers, Leiden.

Colpaert, J. V., van Laere, A. \& van Assche, J. A. 1996. Carbon and nitrogen allocation in ectomycorrhizal and non-mycorrhizal Pinus sylvestris L. seedlings. Tree Physiol., 16, 787-793.

Egger, B., Einig, W., Schlereth, A., Wallenda, T., Magel, E., Loewe, A. \& Hampp, R. 1996. Carbohydrate metabolism in one- and two-year-old spruce needles, and stem carbohydrates from three months before until three months after bud break. Physiol. Plant., 96, 91-100.

Ericsson, T. \& Kähr, M. 1995. Growth and nutrition of birch seedlings at varied relative addition rates of magnesium. Tree Physiol., 15, 85-93.

Ericsson, T., Rytter, L. \& Vapaavuori, E. 1996. Physiology of carbon allocation in trees. Biomass Bioenergy, 11, 115-127.

Eriksson, H. M. 1998. Short-term effects of granulated wood ash on forest soil chemistry in SW and NE Sweden. Scand. J. For. Res., Suppl. 2, 43-55.

Genenger, M. 2001. Effect of wood ash recycling and liquid fertilisation on the fine roots of Norway spruce. Doctoral thesis. Swiss Federal Institute of Technology, Zürich.

Grodzinsky, B., Jiao, J. \& Leaonardos, E. D. 1998. Estimating photosynthesis and concurrent export rates in $\mathrm{C}_{3}$ and $\mathrm{C}_{4}$ species at ambient and elevated $\mathrm{CO}_{2}$. Plant Physiol., 117, 207-215.

Ivashikina, N. V. \& Feyziev, Y. M. 1998. Regulation of nitrate uptake in maize seedlings by accompanying cations. Plant Sci., 131, 25-34.

Jacobson, S. 2001. Fertilization to increase and sustain tree growth in coniferous stand in Sweden. $\mathrm{PhD}$ thesis. Silvestria, 217. Swedish University of Agricultural Sciences.

Klõšeiko, J. \& Mandre, M. 2001. Seasonal dynamics of sugars in the leaves of Salix dasyclados and the effect of soil treatment with cement dust. Proc. Estonian Acad. Sci. Biol. Ecol., 50, 279-291. 
Larsson, P. E. \& Westling, O. 1998. Leaching of wood ash and lime products: laboratory study. Scand. J. For. Res., Suppl. 2, 17-22.

Lawlor, D. W. \& Keys, A. J. 1993. Understanding photosynthetic adaptation to changing climate. In Plant Adaptation to Environmental Stress (Fowden, L., Mansfield, T. \& Stoddart, J., eds), pp. 85-106. Chapman \& Hall, London.

Lejay, L., Gansel, X., Cerezo, M., Tillard, P., Müller, C., Krapp, A., von Wirén, N., Daniel-Vedele, F. \& Gojon, A. 2003. Regulation of root ion transport by photosynthesis: functional importance and relation with hexokinase. Plant Cell, 15, 2218-2232.

Lindberg, S. \& Yahya, A. 1994. Effects of $\mathrm{pH}$ and mineral nutrition supply on $\mathrm{K}^{+}\left({ }^{86} \mathrm{Rb}^{+}\right)$influx and plasma membrane ATPase activity in roots of sugar beets. J. Plant Physiol., 144, 150-155.

Mälkönen, E. 1996. Tuhka kangasmetsien lannoitteena. Metsäntutkimuslaitoksen tiedonantoja, 599, 21-26.

Mandre, M. 1995. Dust emission and deposition. In Dust Pollution and Forest Ecosystems. A Study of Conifers in an Alkalized Environment (Mandre, M., ed.), Publ. Inst. Ecol., 3, 18-22.

Mandre, M. \& Tullus, H. 2002. Partitioning of nutrients and biomass in Scots pine canopy. Proc. Estonian Acad. Sci. Biol. Ecol., 51, 163-172.

Mandre, M., Korsjukov, R. \& Ots, K. 2004. Effect of wood ash application on the biomass distribution and physiological state of Norway spruce seedlings on sandy soils. Plant Soil, 265, 301-314.

Marschner, H. 2002. Mineral Nutrition of Higher Plants. Academic Press, London.

Marschner, H., Kirkby, E. A. \& Cakmak, I. 1996. Effect of mineral nutritional status on shoot-root partitioning of photoassimilates and cycling of mineral nutrients. J. Exp. Bot., 47, 1255-1263.

Martikainen, P. J. 1985. Numbers of autotrophic nitrifiers and nitrification in fertilized forest soil. Soil Biol. Biochem., 17, 245-248.

Mehne-Jakobs, B. 1995. The influence of magnesium deficiency on carbohydrate concentrations in Norway spruce (Picea abies) needles. Tree Physiol., 15, 577-584.

Moilanen, M. \& Issakainen, J. 2000. Tuhkalannoituksen metsävaikutukset. Metsätehon raportti, 93.

Ögren, E. 1999. Fall frost resistance in willows used for biomass production. II. Predictive relationships with sugar concentration and dry matter content. Tree Physiol., 19, 755-760.

Pate, J. S. 1993. Structural and functional responses to fire and nutrient stress: case studies from the sandplains of South-West Australia. In Plant Adaptation to Environmental Stress (Fowden, L., Mansfield, T. \& Stoddart, J., eds), pp. 85-106. Chapman \& Hall, London.

Pettigrew, W. T. 1999. Potassium deficiency increases specific leaf weights and leaf glucose levels in field-grown cotton. Agron. J., 91, 962-968.

Saarsalmi, A., Mälkönen, E. \& Piirainen, M. 2001. Effects of wood ash fertilization on forest soil chemical properties. Silva Fenn., 35, 355-368.

Schachtman, D. P., Reid, R. J. \& Ayling, S. M. 1998. Phosphorus uptake by plants: from soil to cell. Plant Physiol., 116, 447-453.

Steen, E. \& Larsson, K. 1986. Carbohydrates in roots and rhizomes of perennial grasses. New Phytol., 104, 339-346.

Sudachkova, N. E., Shein, I. V., Romanova, L. I., Milyutina, I. L., Kudasheva, F. N., Varaksina, T. N. \& Stepen, R. A. 1997. Biochemical Indicators of Stress of Woody Plants. Nauka, Novosibirsk (in Russian).

Sun, O. J. \& Payn, T. W. 1999. Magnesium nutrition and photosynthesis in Pinus radiata: clonal variation and influence of potassium. Tree Physiol., 19, 535-540.

Total Starch Assay Procedure. 1998. Amyloglucosidase/ $\alpha$-Amylase Method. AACC Method 76.13, Megazyme International Ireland Ltd., Bray.

von Wirén, N., Gazzarrini, S. \& Frommer, W. B. 1997. Regulation of mineral nitrogen uptake in plants. Plant Soil, 196, 191-199.

Wingler, A., Einig, W., Schaeffer, C., Wallenda, T., Hampp, R., Wallander, H. \& Nylund, J.-E. 1994. Influence of different nutrient regimes on the regulation of carbon metabolism in Norway spruce [Picea abies (L.) Karst.] seedlings. New Phytol., 128, 323-330. 


\title{
Kuuseokaste süsivesikute sisalduse sõltuvus mulla töötlemisest puutuhaga
}

\author{
Jaan Klõšeiko, Malle Mandre ja Reet Korsjukov
}

\begin{abstract}
Katsealal töödeldi mulda puutuhaga $\left(0,25,0,5\right.$ ja $1,0 \mathrm{~kg} \mathrm{~m}^{-2}$, töötlemata mulla ala kasutati kontrolliks) ja hinnati töötluste mõju hariliku kuuse (Picea abies L.) okaste süsivesikute sisaldusele ja dünaamikale. Mulla $\mathrm{pH}$-väärtuse suurenemine töödeldud aladel korreleerus heksooside (glükoosi ja fruktoosi) sisalduse vähenemisega okastes. Töödeldud mullal kasvanud puudes ületas fruktoosi ja glükoosi suhe vastavat näitu töötlemata puudes $2-3$ korda. Sahharoosi sisalduses olulisi erinevusi ei leitud. Kasvuperioodi jooksul võib puutuhk vähendada süsivesikute varusid okastes. Süsivesikute sisaldus talvel ei sõltunud puutuhaga töötlemisest.
\end{abstract}

